\title{
Bulk-Fill Resin-Based Composites
}

\author{
Rodrigo Barros, Esteves Lins and Luís Roberto Marcondes Martins* \\ Department of Restorative Dentistry, Piracicaba Dental School, State University of Campinas, Brazil
}

Submission: March 16, 2017; Published: May 04, 2017

*Corresponding author: Luís Roberto Marcondes Martins, DDs MSc PhD Chair Department of Restorative Dentistry, Piracicaba Dental School, State University of Campinas, Tel: +55 19997815425; Email: martins@unicamp.br

\begin{abstract}
Bulk-fill resin composite is a restorative material of great promise for restorative dentistry, presenting success in vitro evaluations. This material was proposed thinking to overlap the problems found in conventional composite resins, which have the negative point the polymerization contraction stress. This new material presents changes in its chemical composition, such as monomeric modification and the initiator system, in order to generate less polymerization contraction. However, longitudinal in vivo studies are of utmost importance for the consolidation of this material as a clinical success.
\end{abstract}

Keywords: Composite resins; Polymerization; Dental restoration, Permanent

\section{Introduction}

Composite resin is the material with the broadest application in restorative dentistry due to its optic and physic properties being very similar to the natural dental tissue, in order to re-establish dental function, form and aesthetic [1,2]. The material presents as its principal characteristic adhesion to the dental structure, avoiding further damage to the dental tissue, however, it presents as disadvantages a strong polymerization contraction stress, with risk of causing marginal gap and staining, microinfiltration, post-procedure sensibility, secondary caries and cusp fracture, characterising a bad prognostic [3-6]. With that in mind, the technology industry developed bulk-fill low-polymerization contraction resins, which permit the insertion of larger quantities of resins and a shorter photopolymerization time. There is an expressive growth on the number of studies regarding this issue in the last five years.

\section{Discussion}

The composite resin polymerization process occur by the creation of polymers from monomers, promoting molecular agglutination, and thus, a contraction derived from the polymerization process, as well as residual tension [7].

The new generation of composite resins, the bulk-fill resins, are the big hit in restorative dentistry, for their superior qualities such as: lower polymerization contraction; a simpler, faster restorative technique, with the insertion of a single increment 4-5 mm thick and photopolymerization time as reduced as 20 seconds in a high potency photopolymerizator [8]. Commercially, we can find bulk-fill resins from two categories: flowable, used as filling or base; restorative, indicated for complete cavity filling, also being malleable.

The chemical modification that this class of composite resins present still demands more studies, due to many important information being legally protected, although it is known that they present modifications on their particle content, being more translucid and permitting better light penetration into deeper layers, being indicated for more voluminous filling [9]; modification of the monomers towards higher molecular mass, denominated "tension modulators", which present bigger chains that can polymerize, and compensate the distance between the polymers $[10,11]$; and an association between traditional photoindicator systems, such as camphorquinone, and new patented systems [12].

Studies report satisfactory results with the use of bulk-fill composite resins, specifically on adhesion [13] and polymerization $[12,14,15]$, nonetheless, future studies must be directed to clinical research for it to be considered effectively a good option of restorative material.

\section{Conclusion}

Bulk-fill composite resins are being largely studied in in vitro assays, presenting very satisfactory results. Notwithstanding, the preoccupation with its clinical effectivity makes future in vivo studies, specially longitudinal studies.

\section{References}

1. Pashley DH, Tay FR, Breschi L, Tjäderhane L, Carvalho RM, et al. (2011) State of the art etch-and-rinse adhesives. Dent Mater 27(1): 1-16. 
2. Nahsan FP, Mondelli RF, Franco EB, Naufel FS, Ueda JK, et al. (2012) Clinical strategies for esthetic excellence in anterior tooth restorations: understanding color and composite resin selection. J Appl Oral Sci 20(2): 151-156

3. Campos EA, Ardu S, Lefever D, Jassé FF, Bortolotto T, et al. (2014) Marginal adaptation of class II cavities restored with bulk-fil composites. J Dent 42(5): 575-581.

4. Dominguez JA, Bittencourt BF, Farago PV, Pinheiro LA, Gomes OMM (2014) Shrinkage stress of resin composites: effect of material composition - sistematic review. Braz Dent Sci 17(3).

5. Benetti AR, Havndrup-Pedersen C, Honoré D, Pedersen MK, Pallesen U (2015) Bulk-fill resin composites: polymerization contraction, depth of cure, and gap formation. Oper Dent 40(2): 190-200.

6. Fronza BM, Rueggeberg FA, Braga RR, Mogilevych B, Soares LE, et al. (2015) Monomer conversion, microhardness, internal marginal adaptation, and shrinkage stress of bulk-fill resin composites. Dent Mater 31(12): 1542-1551.

7. Lee SK, Kim TW, Son SA, Park JK, Kim JH, et al. (2013) Influence of lightcuring units on the polymerization of low-shrinkage composite resins. Dent Mater J 32(5): 688-694.

8. Czasch P, Ilie N (2013) In vitro comparison of mechanical properties and degree of cure of bulk fill composites. Clin Oral Investig 17(1): 227 235.

This work is licensed under Creative Commons Attribution 4.0 Licens

DOI: 10.19080/ADOH.2017.04.555648
9. Omran TA, Garoushi S, Abdulmajeed AA, Lassila LV, Vallittu PK, et al (2016) Influence of increment thickness on dentin bond strength and light transmission of composite base materials. Clin Oral Investig DOI: 10.1007/s00784-016-1953-6.

10. Miletic V, Peric D, Milosevic M, Manojlovic D, Mitrovic N (2016) Local deformation fields and marginal integrity of sculptable bulk-fill, lowshrinkage and conventional composites. Dent Mater 32(11): 14411451.

11. Rauber GB, Bernardon JK, Vieira LC, Maia HP, Horn F, et al. (2016) In Vitro Fatigue Resistance of Teeth Restored With Bulk Fill versus Conventional Composite Resin. Braz Dent J 27(4): 452-457.

12.Zorzin J, Maier E, Harre S, Fey T, Belli R, et al. (2015) Bulk-fill resin composites: polymerization properties and extended light curing. Dent Mater 31(3): 293-301.

13. Van Ende A, De Munck J, Van Landuyt KL, Poitevin A, Peumans M, et al. (2013) Bulk-filling of high C-factor posterior cavities: effect on adhesion to cavity-bottom dentin. Dent Mater 29(3): 269-277.

14. Kim RJ, Kim YJ, Choi NS, Lee IB (2015) Polymerization shrinkage, modulus, and shrinkage stress related to tooth-restoration interfacial debonding in bulk-fill composites. J Dent 43(4): 430-439.

15. Li X, Pongprueksa P, Van Meerbeek B, De Munck J (2015) Curing profile of bulk-fill resin-based composites. J Dent 43(6): 664-672.

\section{Your next submission with Juniper Publishers} will reach you the below assets

- Quality Editorial service

- Swift Peer Review

- Reprints availability

- E-prints Service

- Manuscript Podcast for convenient understanding

- Global attainment for your research

- Manuscript accessibility in different formats

( Pdf, E-pub, Full Text, Audio)

- Unceasing customer service

Track the below URL for one-step submission https://juniperpublishers.com/online-submission.php 